\title{
STEM Education in Ukraine in the Context of Sustainable Development
}

\author{
Oksana Buturlina ${ }^{1}$, Serhii Dovhal ${ }^{2}$, Heorhii Hryhorov ${ }^{3}$, Tetiana Lysokolenko ${ }^{4}$, \\ Vadym Palahuta ${ }^{5}$
}

\begin{abstract}
The conceptual and generalizing experience of STEM education implementation presented in Ukraine reflects the realization of the sustainable development goals through educational innovations. The study is based on the premise that STEM is a component of education for sustainable development. This educational trend focuses on the goals of Education for All (EFA), conforms to the ideas of the education-related Millennium Development Goals (MDGs) and relates to solving societal challenges in the long run. It is argued that the concept of STEM seeks to offer non-standard solutions to global issues in the field of sustainable development, and STEM education should be seen as a mechanism to accelerate the achievement of all sustainable development goals (SDG) and a strategy to obtain each of them. The specifics of STEM key ideas as global educational trends in the national Ukrainian public space are demonstrated. The consideration of STEM education as a component of the strategy for sustainable development through the detailing of the structure and implementation principles as well as STEM competencies, which are defined as the expected result and key for the person of the XXI century, is proved. The experience of Ukrainian research initiatives in the field of STEM education in the context of sustainable development is summarized. A full-fledged programme complex for comprehensive, equitable and high-quality education is presented, which combines the following links: research and experimental work of different levels, teacher's professional development, museums and science centres work, implementation of various educational programmes, festivals and projects to attract young people to STEM, ensuring equal access for girls and boys.
\end{abstract}

Key words: STEM education, sustainable development, sustainable development goals, principles of sustainable development, competency-based approach in education.

\section{Introduction}

Nowadays STEM education is becoming a key area for modernization of the education sector, a component of public policy to strengthen the economy and human capital development, one of the main factors of sustainable innovation for many countries. Development and adoption of the Concept of STEM education development for 2020-

${ }^{1}$ Head of the Department of Information and Educational Projects Management, PhD, Prof. Asoc., Communal Institution of Higher Education «Dnipro Academy of Continuing Education» of Dnipropetrovsk Regional Council. Dnipro. Ukraine. ORCID: https://orcid.org/0000-0002-9603-4752

2 PhD, Prof. Asoc., Department of Information and Educational Projects Management, Communal Institution of Higher Education «Dnipro Academy of Continuing Education» of Dnipropetrovsk Regional Council. Dnipro. Ukraine. ORCID: https://orcid.org/0000-0002-7134-7488

${ }^{3} \mathrm{PhD}$, Prof. Asoc., Department of Natural and Mathematical Education, Communal Institution of Higher Education «Dnipro Academy of Continuing Education» of Dnipropetrovsk Regional Council. Dnipro. Ukraine. ORCID: https://orcid.org/0000-0001-7395-273X

${ }^{4} \mathrm{PhD}$, Prof. Asoc., Department of Philosophy, Communal Institution of Higher Education «Dnipro Academy of Continuing Education» of Dnipropetrovsk Regional Council. Dnipro. Ukraine. ORCID: https://orcid.org/0000-0003-1545-8682 (Corresponding author).

${ }_{5}^{5}$ rofessor, doctor of philosophical sciences, manager of department of engineering pedagogics of the National Metallurgical academy of Ukraine (Dnipro, Ukraine). ORCID: https://orcid.org/0000-0003-4254-1625 
2027 in Ukraine in 2020 is an important step on the way to large-scale innovation (The concept of the development of natural and mathematical education, 2020). The efforts of early followers of innovation have led to forming a critical field of scientific, methodological and pedagogical developments; taking into consideration the implemented projects and unique infrastructure we may speak about creating a national system of STEM education.

In general education is in a central place on the proposed 2030 sustainable development agenda. Within the framework of the Incheon Declaration, education is allocated to a separate goal which is SDG 4 'Ensure inclusive and equitable quality education and promote lifelong learning opportunities for all' (UNESCO, 2015) and has challenges in education within other areas, including health, economic growth and employment, sustainable consumption and production, and climate change. Innovative and quality education, which is STEM education, can accelerate the achievement of all SDGs and therefore should become a part of strategies to obtain each of them. At the same time, Ukraine now faces an important task of creating a reliable economic system that meets the national security strategy, strengthening competitiveness in accordance with the goals of sustainable balanced development. It is possible to achieve the set goals on the basis of effective interaction of economy, science and education, re-equipment of production and attraction of innovative technologies.

However, we note without going into a detailed analysis of macro- and microeconomic indicators that during the years of independence there was a significant decline in Ukraine's economy, which shifted it from the $10^{\text {th }}$ place in Europe to the last one. The state's share in the world GDP decreased from $1.3 \%$ in 1991 to $0.29 \%$ in 2018 . Ukraine's macroeconomic indicators remain low: GDP in 2018 in dollar terms is 130.832 billion US dollars, compared to 183.31 billion US dollars in 2013 (Debt statistics of Ukraine, 2020). When choosing a course to strengthen its competitiveness, Ukraine relies on its own key advantages in the world market, which traditionally include: quality of education, innovation, high human capital index and strong social intercourse. Foresight of Socio-Economic Development of Ukraine in 2016 defined them as basic ones. The level of the human capital index is $63 \%$, which is traditionally higher than in other countries with similar levels of economic development but lower than in European countries in general. World Bank research shows that significant investment in education, health and social protection is needed for Ukrainians to realize full human capital (Zgurovsky, 2016).

Having adopted the UN "Sustainable Development Goals" in 2015, Ukraine declared its readiness to fight for the sustainable development of the planet. Ukrainian experts adapted 17 global goals to the specifics of national development and presented a national report "Sustainable Development Goals: Ukraine" in September 2017. (Sustainable Development Goals: Ukraine, 2017). Assessing the state of achievement of the Millennium Development Goals by Ukraine during 2000-2015, the authors of the report note that despite the general increase in the coverage of children with general secondary education ( $98.3 \%$ of school-age children), the coverage of $40.9 \%$ of young people aged 17-24 with higher education, it is necessary to ensure compliance of educational training with the requirements of the labour market (taking into account the forecast trends in economic development) (Sustainable Development Goals: Ukraine, 2017). Foresight of Socio-Economic Development of Ukraine in the short and long term 
until 2030 is determined by the main drivers of the economy and economic growth of mechanical engineering, metallurgy, IT, construction, agriculture, transport, science, and high-tech production. In the XXI century, they are generally called STEM industries related to science, technology, engineering-based human activities. The experts in these industries make the most significant contribution to the production of gross domestic product and their deficit is particularly noticeable in Ukraine as well as around the world. An important reason for this deficit is the loss of popularity of scientific and technical, and engineering professions; as a consequence, interest in studying natural, technological, educational and mathematical subjects among young people is low as evidenced by the negative dynamics of the number of graduates who choose mathematics, physics, chemistry and biology for external independent testing.

Comparative statistical data from 2012 to 2019 show that the number of graduates who take the external independent testing in physics has tripled from 67 thousand to 23 thousand, and in chemistry - from 48 thousand to 15 thousand, when the total number of graduates ranges within 300 thousand (Ukrainian Centre for Educational Quality Assessment, 2019) (Table 1).

Table 1. "Quantitative index of external independent testing (EIT) in Ukraine"

\begin{tabular}{|c|c|c|c|}
\hline $\begin{array}{c}\text { The } \\
\text { year of EIT }\end{array}$ & $\begin{array}{c}\text { The total } \\
\text { number entrants } \\
\text { who passed EIT }\end{array}$ & $\begin{array}{c}\text { The } \\
\text { number of entrants } \\
\text { who passed EIT in } \\
\text { physics }\end{array}$ & $\begin{array}{c}\text { The number } \\
\text { of entrants who passed } \\
\text { EIT in chemistry }\end{array}$ \\
\hline 2012 & 324139 & 67555 & 46727 \\
\hline 2013 & 315858 & 69763 & 50423 \\
\hline 2014 & 290655 & 66692 & 49208 \\
\hline 2015 & 267394 & 51463 & 39730 \\
\hline 2016 & 267172 & 35892 & 24811 \\
\hline 2017 & 239945 & 26491 & 21978 \\
\hline 2018 & 333171 & 23405 & 15476 \\
\hline 2019 & 349365 & 23485 & \\
\hline
\end{tabular}

In these conditions, STEM education should become a key area of education, a component of public policy to strengthen the competitiveness of the economy and human capital development, one of the main factors of innovative educational development that meets the demands of modern economy and society. In addition, in the context that education for sustainable development should be innovative and proactive, the national report "Sustainable Development Goals: Ukraine" identifies recommendations for achieving the Sustainable Development Goals. These include reforming the education sector, updating education standards; ensuring equal access to education and vocational training for vulnerable groups, especially people with disabilities and vulnerable people; updating the content of education through the introduction of curricula on sustainable development, rational consumption, human rights, gender equality, culture, social cohesion, peace and non-violence, etc. and ensuring the principle of conformity of education to the needs of social development (Sustainable Development Goals: Ukraine, 2017). Taking the above mentioned into consideration, it should be noted that STEM education is an important component of the concept of sustainable development, which in terms of projection is designed to respond to current and future demands of 
generations. In this paper, an attempt is made to conduct a conceptual analysis of incorporating STEM education in Ukraine in the context of implementing sustainable development ideas.

\section{Literature Review}

Today, a number of studies are devoted to the role of STEM education for sustainable development. Thus, (Smith \&Watson, 2016), (Yanez, Thumlert, de Castell \& Jenson, 2019) reflect on the intersections of STEM education and education for sustainable development, because education has an impact on the fact who and how will implement the ideas of sustainable development. And education itself should be seen as STEM, as a close collaboration of science, technology, engineering and mathematics. Conducting the literature review of these two topics, the authors analyze the ways of integrating STEM education and sustainable development, offering options for starting principles for future initiatives. The research "Education for Sustainable Development in STEM (Technical Drawing): Learning Approach and Method for SDG 11 in Classrooms” presents the Spanish experience of implementing the purposes of sustainable development through components of STEM education (Velázquez \& Rivas, 2020). The research "Education for Sustainable Development: The STEM Approach in Universiti Sains Malaysia" summarizes the experience of implementing research programmes through the use of STEM approach (Teh \& Koh, 2020).

The aspects of using pedagogical STEM approaches to ensure the implementation of concepts of sustainability in the educational process are analyzed in the research 'STEM Education in Secondary Schools: Teachers' Perspective towards Sustainable Development", whose authors believe that an integrated STEM approach can turn education into an innovative environment and sustainable development (Nguyen, TP, Nguyen, TH, \& Tran, TK, 2020). The research by Pitt, J (2009) suggests the idea that the use of sustainability contexts in STEM education can provoke critical discussions in the socio-educational space and, thus, create new opportunities for sustainable development education. There are also a number of case studies on STEM, which are directly devoted to the implementation of such goals of sustainable development as ensuring quality education, ensuring gender equality, etc. (United Nations General Assembly, 2015). Various options for integrating STEM into education are highlighted in the following researches: "A Conceptual Framework for STEM Integration Into Curriculum Through Career and Technical Education" (Asunda, 2014), "Practicing engineering while building with blocks: identifying engineering thinking" (Bagiati \& Evangelou, 2016), "Effects of integrative approaches among science, technology, engineering, and mathematics (STEM) subjects on students' learning: A preliminary meta-analysis" (Becker, \& Park 2011), "Transfer of Learning: Connecting Concepts during Problem Solving" (Dixon \& Brown, 2012), "An analysis of Australian STEM education strategies. Policy Futures in Education" (Murphy at al., 2018), "Makerspace in STEM for girls: A physical space to develop twentyfirst-century skills" (Sheffield at al., 2017), "The Effect of STEM Project Based Learning on Self-Efficacy among High-School Physics Students" (Samsudin at al., 2020). Perez, Cromley \& Kaplan (2014), Wang \& Degol (2013, 2017), Allen \& Eisenhart (2017) study the causes of underrepresentation of girls and women in the STEM fields. 
The presented research methodology suggests that STEM education is closely related to the mechanisms for achieving sustainable development goals, both directly and indirectly, through a comprehensive approach to solving tasks, innovation and a long-term focus.

\section{Development}

STEM philosophy defines the understanding of the relationship between the fields of science, technology, and engineering as well as between the purpose of STEM education and its role in the development of the country. STEM education seeks to develop and propose innovative solutions to global issues, including those directly related to the 2030 Sustainable Development Goals (United Nations General Assembly, 2015). A transdisciplinary approach to learning is based on the practical application of academic knowledge to solve real-world problems. Establishing social dialogue, relations between school, community, and economy contributes to the development of STEM competencies of a competitive individual. Problem-searching, practice-based nature of learning makes the study of science, technology, engineering and mathematics socially significant.

The concept of the development of natural and mathematical education (STEM education) in Ukraine aims to comprehensively disseminate innovative teaching methods and combine the efforts of educational participants and social partners in shaping young people's competencies which are necessary to achieve the SDGs sustainable development goals that contribute to finding solutions to global and local societal problems, combining science, technology, engineering and mathematics. The Concept declaring STEM ideas at the state level for the first time, considerable attention in the document is paid to the list of students' STEM competencies. (The concept of the development of natural and mathematical education, 2020).

They are defined as the expected result of implementation and as key for the person of the XXI century. Developers consider STEM competence to be an individual's ability to apply the knowledge, skills, and attitudes associated with STEM subjects appropriately in the daily lives, workplaces, or education. It is not limited to the traditional boundaries of individual knowledge sets (e.g. physical competence or digital competence) and covers the skills to apply the acquired knowledge, taking into account ethical positions and values. Today, STEM competencies are also important for non-STEM professions. After all, an employee with STEM competence is able to effectively use the knowledge, skills and attitude of STEM to effectively perform technical or professional tasks. Likewise, a citizen with STEM competence has the authority to improve his or her life on a daily basis, while contributing to the achievement of the SDG's sustainable development goals for the just, inclusive and holistic development of his or her country and the world.

Researchers (Boon Ng (2019), Velázquez \& Rivas (2020) of the issue of forming these integrative skills pay attention to the list of competencies that should be developed within STEM education. They are cognitive skills, information processing skills: interpretation and analysis of data; problem-solving ability and engineering thinking; manipulative and technological skills; algorithmic thinking and digital literacy; research skills; design thinking, creativity and innovation; communication and collaboration skills. 
Let's dwell on some of them in more detail (The concept of the development of natural and mathematical education, 2020).

Cognitive skills are the ability to learn, cognitive flexibility, attention, memory; analytical, critical, creative thinking; argumentation, search for ideas, decision-making, ability to observe and draw conclusions. These skills trigger and support mathematical thinking, which allows us to operate with numbers to systematize, critically evaluate a set of problems, and find solutions.

Information literacy (information processing, interpretation and analysis of data) is the ability to quickly and efficiently find, compare, select, process information for specific needs; understanding, interpretation, analysis and extrapolation of empirical data, verification, reliability, display of results in effective ways.

Problem solving and engineering thinking are identifying, destroying and developing solutions to complex problems based on data analysis, evaluation of options and implementation of solutions. Problem solving is a feature of STEM research and STEM careers. The factors such as safety and sustainability, as well as the needs of the customers, need to be considered when developing solutions or products. Problem solving requires engineering thinking to find the optimal creative way to solve problems, adapt, visualize and improve prototypes that correspond to the stages of engineering design.

Scientific literacy and research skills mean mastering a systematic methodology of scientific research, which includes conducting research, manipulative skills to observe phenomena, the ability to suggest, justify and test hypotheses, conduct an experiment, analyze data and develop conclusions that confirm or reject hypothesis. They promote critical, creative, analytical and systematic thinking. It also includes observation, classification, measurement, inference, forecasting, and communication, use of space-time relationships, data interpretation, operational determination, and control of variables. Research skills, knowledge and relevant scientific attitudes are important when evaluating young people according to the PISA and TIMMS procedures.

Algorithmic thinking and digital literacy are considered as the effective use of digital technologies, including the possession of a computer, a tablet or a mobile phone and Internet services to communicate, search, process and present data, formulate problems and present solutions in the form of computer algorithms that can be used by the machine; compilation of instructions or algorithms that will allow intelligent systems to perform certain tasks; logical thinking, pattern recognition, abstraction.

Design thinking, creativity and innovation are considered as the structure of creative strategies and processes for developing solutions and products; the ability to make creative ideas viable and set them up for work, guided by inspiration, empathy. Design thinking integrates critical and creative thinking, using stages of information gathering, creative brainstorming, ideas, prototyping, trial and error, review, redesign, improvement, testing and implementation. Creativity is the ability to use the imagination to create something. A creative person can perceive the world in different and sometimes completely new ways, establishing connections between phenomena. Innovation is the ability to make changes and improve existing products, processes and systems.

Manipulative and technological skills are psychomotor skills associated with the correct and safe use of scientific and technical equipment, apparatus, and samples of substances specific to a particular industry. Vocational skills must be predictable and in 
line with labor market dynamics. Vocational education institutions and employers must determine what types of skills to focus on and what forms of training to use. This is compliant with the goals of sustainable development in order to bring education in line with the demands of society and the economy.

Communicative skills include communication skills, effective teamwork. Effective collaboration gives each team member an equal chance to participate and share ideas within shared responsibility. Setting common goals gives the team the opportunity to share responsibility for achieving them. The main skills are the ability to work independently and in a team, to be a leader and a performer, to understand own place and role, to know own strengths and weaknesses, to communicate with team members or stakeholders in clear and effective ways. This demonstrates that the Ukrainian STEM education is based on the following principles:

- personal approach, taking into account the age, individual characteristics of students, their interests and inclinations;

- permanent updating of the content (the content of STEM education is constantly updated taking into account the achievements of science and technology development);

- continuity: formation of natural and mathematical, technological literacy and STEM competencies at all levels of education (from preschool to higher education);

- transdisciplinarity: the movement from monodisciplinarity, duality, integration to a transdisciplinary approach when constructing educational and training programs of educational institutions of different levels;

- patriotism and civic orientation (STEM education is aimed at increasing the human potential of the country, increasing its competitiveness);

- productive motivation (formation of productive motivation of STEM educational process participants to carry out research and project activities, inventions).

Taking all the above mentioned into consideration, it can be assumed that these principles reflect the complexity of the STEM approach to address the main challenges of sustainable development in terms of polydisciplinarity, flexibility and a high level of adaptability to implementation opportunities.

The concept of the development of natural and mathematical education (STEM education) in Ukraine (2020) determines the priority areas of STEM education development such as fundamental natural and mathematical, technological education; development of scientific and technical creativity of children and youth; development of innovative STEM programs to attract students, ensuring the principles of transdisciplinarity and forming a holistic worldview; development of current educational programmes and formation of a group of STEM teachers; expansion and strengthening of partnership cooperation in the system of school - institutions of vocational education - institutions of higher education - employers; popularization of STEM education and STEM professions, career support of youth; ensuring gender parity in STEM education and STEM fields, involving girls in STEM education.

The structure of STEM education in Ukraine is determined by legislative acts in the field of education, the State standard of basic general secondary education and the standards of specialized scientific education.

The main stages for implementing STEM education are: 
primary education which is carried out in preschool education institutions, primary schools, where students are engaged in primary scientific and technical creativity. The main task is to stimulate curiosity and support interest in learning, knowledge, motivation for independent research, creating simple devices, structures;

basic education which is carried out in the general secondary and out-of-school education in order to form steady interest to natural and mathematical subjects, involve in research, invention, project activity, promote such professions as an engineer, a scientist, a researcher;

field-specific education is carried out on the basis of field-specific senior school of comprehensive secondary and out-of-school education institutions. The main task is to promote the conscious choice of further education of the STEM specialization, in-depth mastering of the system of knowledge and skills in STEM subjects, mastering of research methods;

professional / higher education ensures forming STEM specialists; it is carried out on the basis of vocational / higher education institutions and through improving teachers' professional skills to implement new learning technologies, including STEM courses; implementation and realization of STEM projects.

STEM education in Ukraine is supported and carried out through all types of education: formal - full-time, part-time, distance, network; non-formal, informal - on the basis of online platforms, STEM centres / laboratories, virtual STEM centres, excursions, quests, competitions, festivals, hackathons, workshops, using the opportunities of public and private partnership, etc.

In order to ensure equal access to quality education for students of different ages, including students with special educational needs; modern network and distance forms of educational communication are used when providing STEM education.

Like most developed countries, Ukraine has already had a global approach to STEM at the national level. It encompasses a number of initiatives that promote STEM competencies and is aimed at encouraging young people to STEM research and STEM careers.

Let's focus on current programs and projects in Ukraine aimed at developing teachers' professional skills, ensuring their motivational and technological readiness; forming STEM competencies of children and youth; promoting science and technology; supporting girls, etc. After all sustainability and environmental protection are important topics for students throughout Europe. The way we deal with these issues will shape our future. Motivated and skilled teachers are the key to enable students to meet the challenges of tomorrow. This is especially true for STEM teachers. They share important knowledge with students in order to form understanding the problems and to create possible solutions (Science on Stage Europe, 2020).

The compiled list is not limiting, it presents the most important, in the authors' opinion, projects and programmes.

1.Creation of specialized national / regional and local STEM centres, STEM laboratories, STEM embassies. There are such working centres as the Museum of Science of the Small Academy of Sciences, opened in 2020, the STEM embassy in leading universities (Landau Centre, Noosphera). STEM Centres in the regions of Ukraine are equipped using the state subvention annually in the amount of UAH 900 million. Local 
STEM laboratories are created on the basis of comprehensive secondary and out-of-school education institutions at the expense of the local budget within the framework of grant support.

2.Development of effective and attractive educational programmes, innovative methods of implementation. An example is the programme of an elective course for 5-9grade students in secondary schools "STEM-LAB". The aim of the programme is to create concrete and practical learning concepts that encourage students to be active and responsible citizens, developing their interest in STEM subjects. Within the course, students can explore issues of science, technology, the world, society, economics and sustainable development. The main idea is to show children that science and technology, STEM subjects, are designed to solve the problems of the environment, health and sustainability. The programme is based on the classification of professions (5 types - 5 topics) in the field of "Man-Man", "Man-Technique", "Man-Nature", "Man-Sign", "ManImage". When studying, students learn new and deepen previously acquired knowledge in science, mathematics, engineering and technology, use a mathematical apparatus for measurements, design instruments and objects, develop and present projects. They get acquainted with the professions related to the issues studied in the course. Thus, in the 5th grade students will learn what STEM profession is (Introduction), get acquainted with the professions of their school, explore the problems of energy efficiency of educational institutions, develop projects to optimize energy consumption in the computer classes, build models of the school of the future (the topic "The school of my dreams"). Working on the topic "Wings. Why do they fly?" children will get acquainted with the concept of force, types of forces, learn why objects of the natural and artificial world fly, they will be able to make their own plane and explore how it flies. Also children learn the professions of aviation industry. The topic "Space travel" helps children to improve the knowledge about the structure of the universe received in the course of science, to learn about the development of the space industry, existing professions, to learn about the problems faced by astronauts when going into outer space, to develop protective clothing and to send a postcard in the future.

3. In addition to existing school programmes, a number of educational and training programmes for young people have been launched; they promote the development of scientific and technical creativity and encourage the choice of STEM professions. A striking example is the Mechatronic-LAB programme, launched in 2018 by the industrial company Interpipe. The programme involves such categories of participants as high school students, students of vocational schools and high educational institutions. In 2020, the Mechatronic-LAB competition became a part of the national stage of WorldSkills. It is also worth mentioning such programmes as "Energy Efficient School: New Generation", which offers courses for students of different ages on energy efficiency, conscious smart consumption from DTEK, short-term educational programmes created by leading polytechnics of Ukraine: STEM-CAMP with National Technical University "Kharkiv Polytechnic Institute", Summer Flight School with the National Aerospace University H.E. Zhukovsky "Kharkiv Aviation Institute", "Space Quest" with Oles Honchar Dnipro National University, etc.

4.Special attention should be paid to programmes for promoting and involving girls in STEM. Over the past three years, they have gained popularity and attracted the 
attention of active girls, contributing to the destruction of stereotypes about non-girls' professions. In Ukraine there are such programmes as "STEM Girls" from the NGO "Centre for the Development of Corporate Social Responsibility"; "STEM IS FEM" is a Ukrainian initiative from women scientists of Ukrainian universities and "Techno-girls" from the project "STEM at the Dnipro" and Interpipe. The latter is an educational and training programme for girls, consisting of 4 modules in the areas of making, media creativity, programming and design of smart devices, project management. Schoolgirls aged 10 to 18 are involved.

5.Motivated and qualified teachers are able to pass on the necessary knowledge to students and teach them to research independently, understand problems and find innovative ways to solve them. They play a crucial role in educating young people about the challenges of achieving the Sustainable Development Goals. In Ukraine a number of activities to improve the teachers' skills, preparing them for the introduction of STEM innovations have been developed. One of the most interesting opportunities is provided by the All-Ukrainian WEB-STEM-SCHOOL, which has been gathering enthusiastic teachers twice a year during 2017-2020. Education at school is based on the principle of "peer-to-peer". Anyone with interesting experience can share life hacks with his or her colleagues. The project is implemented under the leadership of the State Scientific Institution "Institute of Education Content Modernization" and the project "Quality of Education" with the participation of regional institutions of postgraduate pedagogical education. Training materials are presented in the form of video and posted on the platform "Quality of Education". Every year, more than 10,000 teachers improve their skills in this way.

6.The experimental implementation of innovative models and directions in comprehensive secondary and out-of-school education institutions under the guidance of scientific institutions is the most systematic in Ukrainian STEM education. Table 2 presents pedagogical research on the main areas of implementation of STEM education, which contribute to the scientific and methodological support of participants' innovative activities in the educational process. The largest one unites 45 experimental educational institutions and was held during 2016-2020 in Dnipropetrovsk region on the topic "Scientific and methodological principles of creating an innovative model of STEM education" under the guidance of scientists of the Communal Institution of Higher Education "Dnipro Academy of Continuing Education". This scientific and pedagogical project unites more than 2,500 teachers and 24,000 students. The network of experimental institutions was formed, a set of activities to improve the teachers' skills and master the methodology of STEM was developed, and a creative environment for the development of students' STEM competencies was created. 
Table 2. "Pedagogical research in the main areas of STEM education in Ukraine"

\begin{tabular}{|c|c|c|c|}
\hline $\begin{array}{l}\text { The title of the } \\
\text { programme, project }\end{array}$ & $\begin{array}{l}\text { The initiator, the } \\
\text { organizers }\end{array}$ & Links & Essence and content \\
\hline \multicolumn{4}{|c|}{ Experimental work of different levels } \\
\hline $\begin{array}{l}\text { Scientific and } \\
\text { methodological } \\
\text { principles of creating } \\
\text { an innovative model } \\
\text { of STEM education }\end{array}$ & $\begin{array}{l}\text { the Communal Institution } \\
\text { of Higher Education } \\
\text { "Dnipro Academy of } \\
\text { Continuing Education" }\end{array}$ & $\begin{array}{l}\text { https://site } \\
\underline{\text { s.google.co }} \\
\mathrm{m} / \text { dano.dp. } \\
\underline{\text { ua/stem } /}\end{array}$ & $\begin{array}{l}\text { Network of experimental } \\
\text { institutions of Dnipropetrovsk } \\
\text { region (45 institutions of different } \\
\text { types) }\end{array}$ \\
\hline $\begin{array}{l}\text { Scientific and } \\
\text { methodological } \\
\text { principles of creation } \\
\text { and functioning of } \\
\text { the All-Ukrainian } \\
\text { scientific and } \\
\text { methodical virtual } \\
\text { STEM centre }\end{array}$ & $\begin{array}{l}\text { Small Academy of Sciences } \\
\text { of Ukraine }\end{array}$ & $\frac{\underline{\text { https: } / / \text { ste }}}{\text { mua.science }}$ & $\begin{array}{l}\text { Centre for real and virtual } \\
\text { educational research aimed at } \\
\text { supporting and developing STEM } \\
\text { education in Ukraine. }\end{array}$ \\
\hline $\begin{array}{l}\text { Creation and testing } \\
\text { of a methodical } \\
\text { system of teaching } \\
\text { the basics of } \\
\text { robotics as a } \\
\text { component of } \\
\text { STEM education }\end{array}$ & $\begin{array}{l}\text { Communal educational } \\
\text { institution "Educational } \\
\text { complex" } 141 \\
\text { "Educational resources and } \\
\text { technological training } \\
\text { (ERT) }\end{array}$ & $\begin{array}{l}\frac{\text { ttp://www. }}{\text { ortlyceum.ki }} \\
\text { ev.ua/page/ } \\
\text { vseukrayins } \\
\text { kij_eksperi } \\
\text { ment_z_rob } \\
\text { ototehniki }\end{array}$ & $\begin{array}{l}\text { Development of a methodical } \\
\text { system of teaching the basics of } \\
\text { robotics in a secondary school as a } \\
\text { component of STEM education } \\
\text { Development of } \\
\text { curricula for elective courses, } \\
\text { electives, clubs, special courses. } \\
\text { Development of } \\
\text { educational and methodical support } \\
\text { of the robotics course: educational, } \\
\text { educational and methodical } \\
\text { manuals, electronic resources. }\end{array}$ \\
\hline \multicolumn{4}{|c|}{ Advanced teachers training } \\
\hline $\begin{array}{l}\text { Educational } \\
\text { programme "WEB- } \\
\text { STEM-school 2017- } \\
\text { 2021" }\end{array}$ & $\begin{array}{l}\text { the State Scientific } \\
\text { Institution "Institute of } \\
\text { Education Content } \\
\text { Modernization", the } \\
\text { project "Quality of } \\
\text { Education", regional } \\
\text { institutions of postgraduate } \\
\text { pedagogical education }\end{array}$ & $\begin{array}{l}\frac{\text { http://vakis }}{\text { tosviti.com. }} \\
\text { ua/uk/web- } \\
\text { stem- } \\
\text { shkola-2020 } \\
\end{array}$ & $\begin{array}{l}\text { Video lessons and master classes } \\
\text { from leading specialists of Ukraine } \\
\text { on the theory and practice of STEM } \\
\text { education }\end{array}$ \\
\hline $\begin{array}{l}\text { Qualification } \\
\text { modular programme } \\
\text { for pedagogical and } \\
\text { scientific- } \\
\text { pedagogical workers } \\
\text { "Be STEM" }\end{array}$ & $\begin{array}{l}\text { the Communal Institution } \\
\text { of Higher Education } \\
\text { "Dnipro Academy of } \\
\text { Continuing Education" }\end{array}$ & $\begin{array}{l}\text { http://dano } \\
\text { dp.ua/uk/ }\end{array}$ & $\begin{array}{l}\text { A number of educational } \\
\text { programmes of different durations } \\
\text { on the topics of theoretical and } \\
\text { practical aspects of STEM } \\
\text { implementation. }\end{array}$ \\
\hline STEM-CAMP & $\begin{array}{l}\text { Metinvest and the } \\
\text { Dealership Academy }\end{array}$ & & $\begin{array}{l}\text { Educational programme for } \\
\text { teachers of Zaporizhia, Kryvyi Rih } \\
\text { and Mariupol }\end{array}$ \\
\hline \multicolumn{4}{|c|}{ Museums, festivals and centres of science and technology } \\
\hline $\begin{array}{l}\text { Small Academy of } \\
\text { Sciences of Ukraine }\end{array}$ & $\begin{array}{l}\text { National Academy of } \\
\text { Sciences of Ukraine }\end{array}$ & $\begin{array}{l}\text { http://man. } \\
\text { gov.ua/ua }\end{array}$ & $\begin{array}{l}\text { Centre for Scientific Education of } \\
\text { the II category under the auspices of } \\
\text { UNESCO }\end{array}$ \\
\hline
\end{tabular}




\begin{tabular}{|c|c|c|c|}
\hline $\begin{array}{l}\text { Museum of Science } \\
\text { of Small Academy of } \\
\text { Sciences of Ukraine }\end{array}$ & $\begin{array}{l}\text { Small Academy of Sciences } \\
\text { of Ukraine, Ministry of } \\
\text { Education and Science }\end{array}$ & $\begin{array}{l}\frac{\text { https://scie }}{\text { ncemuseum }} \\
\text {.com.ua/ }\end{array}$ & $\begin{array}{l}\text { the first state museum, where it is } \\
\text { forbidden NOT to touch the } \\
\text { exhibits. The visitor will find himself } \\
\text { or herself in a space where the most } \\
\text { important scientific achievements of } \\
\text { mankind, their laws and interaction } \\
\text { are demonstrated in an } \\
\text { understandable and accessible form. }\end{array}$ \\
\hline $\begin{array}{l}\text { Educational Centre } \\
\text { "LandauCentre" }\end{array}$ & $\begin{array}{l}\text { V. N. Karazin Kharkiv } \\
\text { National University, } \\
\text { Association of graduates, } \\
\text { teachers and friends of the } \\
\text { university }\end{array}$ & $\begin{array}{l}\text { http://land } \\
\frac{\text { aucentre.org }}{\text { /about/ }}\end{array}$ & $\begin{array}{l}\text { Its purpose is to stimulate the } \\
\text { revival of lost interest in science } \\
\text { (especially among young people) } \\
\text { and to establish the first unique } \\
\text { university centre (within Ukraine) of } \\
\text { intellectual leisure for Kharkiv } \\
\text { residents and guests of the city. }\end{array}$ \\
\hline $\begin{array}{l}\text { Museum of Popular } \\
\text { Science and } \\
\text { Technology } \\
\text { "Experimentanium" }\end{array}$ & $\begin{array}{l}\text { LLC "museum of science } \\
\text { and technology" } \\
\text { experimentanium" }\end{array}$ & $\begin{array}{l}\frac{\text { http://expe }}{\text { rimentaniu }} \\
\underline{\text { m.com.ua/ }}\end{array}$ & $\begin{array}{l}\text { educational and entertainment } \\
\text { centre for children and adults. The } \\
\text { permanent exposition of the } \\
\text { Experimentanium Museum has } \\
\text { collected more than } 300 \text { interactive } \\
\text { exhibits and is devoted to } \\
\text { mechanics, optics, electricity, } \\
\text { magnetism and acoustics. } \\
\text { Departments: Anatomical, Secrets } \\
\text { of Water, Latest Technologies and } \\
\text { the updated exposition "Mechanics } \\
\text { of da Vinci". Also visitors will find } \\
\text { optical illusions, puzzles, laser and } \\
\text { mirror mazes at the Museum. } \\
\text { Independent visits, scientific shows, } \\
\text { excursions for schoolchildren and } \\
\text { holidays. }\end{array}$ \\
\hline Water Museum & $\begin{array}{l}\text { Municipal Enterprise } \\
\text { "Water-Information } \\
\text { Centre" ("Water } \\
\text { Museum") }\end{array}$ & $\begin{array}{l}\frac{\text { https://leov }}{96 . \text { wixsite.c }} \\
\text { om/aqua1 }\end{array}$ & $\begin{array}{l}\text { improving public awareness of } \\
\text { water values and raising awareness } \\
\text { of the importance of their } \\
\text { conservation and rational use. The } \\
\text { exposition of the centre tells about } \\
\text { the role of water in nature and } \\
\text { human life, about the history of } \\
\text { Kyiv water supply, technologies of } \\
\text { water purification and } \\
\text { transportation to the consumer, } \\
\text { drainage and wastewater treatment. } \\
\text { There is also a playground in the } \\
\text { exhibition. }\end{array}$ \\
\hline Interpipe Tech Fest & $\begin{array}{l}\text { Open Joint-Stock } \\
\text { Company "INTERPIPE } \\
\text { NTRP" }\end{array}$ & $\begin{array}{l}\frac{\text { http://techf }}{\text { est.interpipe }} \\
\text { biz/ }\end{array}$ & $\begin{array}{l}\text { The Festival of Science, Technology } \\
\text { and Modern Technologies. Held } \\
\text { annually since 2016. The goal is to } \\
\text { return engineering, science and } \\
\text { industry to the agenda of the } \\
\text { modern Ukrainian; to increase the } \\
\text { interest of young people in STEM } \\
\text { subjects and natural sciences, to } \\
\text { stimulate a conscious choice of } \\
\text { technical professions. }\end{array}$ \\
\hline
\end{tabular}




\begin{tabular}{|c|c|c|c|}
\hline & & & $\begin{array}{l}\text { The festival consists of an } \\
\text { exhibition of modern engineering, } \\
\text { wow-activities, technical } \\
\text { competitions and a lecture room. }\end{array}$ \\
\hline $\begin{array}{l}\text { Miniphenomenon: } \\
52 \text { exciting } \\
\text { experiments for } \\
\text { lessons and breaks }\end{array}$ & $\begin{array}{l}\text { Federation of Employers' } \\
\text { Organizations of } \\
\text { Dnipropetrovsk Region, } \\
\text { German Association } \\
\text { NORDMETALL }\end{array}$ & $\begin{array}{l}\frac{\text { http://ford. }}{\text { gs.dp.ua/arc }} \\
\underline{\text { hives } / 1845}\end{array}$ & $\begin{array}{l}\text { Mobile museum of science, the } \\
\text { stands of which illustrate physical } \\
\text { and technical phenomena }\end{array}$ \\
\hline \multicolumn{4}{|c|}{ The projects to support girls in STEM } \\
\hline STEM Girls & $\begin{array}{l}\text { Public Union } \\
\text { "Centre for Corporate } \\
\text { Social Responsibility" } \\
\end{array}$ & $\begin{array}{l}\text { https://girls } \\
\text {-stem.org } /\end{array}$ & $\begin{array}{l}\text { Promoting STEM among girls, } \\
\text { organizing mentoring programmes }\end{array}$ \\
\hline Techno-girls & $\begin{array}{l}\text { Open Joint- } \\
\text { Stock Company } \\
\text { "INTERPIPE NTRP" and } \\
\text { the Communal Institution } \\
\text { of Higher Education } \\
\text { "Dnipro Academy of } \\
\text { Continuing Education" }\end{array}$ & $\begin{array}{l}\frac{\text { ttps://www }}{\text { facebook.c }} \\
\frac{\text { om/interpip }}{\text { e.techfest/p }} \\
\underline{\underline{\text { osts } / 234852}} \\
\underline{9498693346} \\
L\end{array}$ & $\begin{array}{l}\text { Training programme for girls aged } \\
10-17\end{array}$ \\
\hline STEM is FEM & IT-companies of Ukraine & $\begin{array}{l}\frac{\text { ttps: } / / \text { stemi }}{\text { sfem.org/ }} \\
\underline{\underline{y}}\end{array}$ & $\begin{array}{l}\text { Training programmes } \\
\text { for girls in the areas of } \\
\text { biotechnology, mechanical } \\
\text { engineering, agro technology, etc. }\end{array}$ \\
\hline \multicolumn{4}{|c|}{ Educational STEM programmes for children and youth } \\
\hline $\begin{array}{l}\text { Interpipe } \\
\text { Mechatronic LAB }\end{array}$ & $\begin{array}{l}\text { Open Joint-Stock } \\
\text { Company “INTERPIPE } \\
\text { NTRP”, National } \\
\text { Technical University } \\
\text { «Dnipro Polytechnic», } \\
\text { «STEM at the Dnipro» }\end{array}$ & $\begin{array}{l}\text { https://elpr } \\
\text { ivod.nmu.or } \\
\text { g.ua/ua/ent } \\
\underline{\text { rant/iml/ }} \\
\underline{\text { https://ww }} \\
\underline{\text { w.facebook. }} \\
\underline{\text { com/group }} \\
\underline{\text { s/JuniorMe }} \\
\text { chatronic }\end{array}$ & $\begin{array}{l}\text { Training programme for } \\
\text { schoolchildren and students in the } \\
\text { field of industrial mechatronics at } \\
\text { the educational stands FESTO and } \\
\text { FISHERNECHNIC }\end{array}$ \\
\hline Technocraft & Metinfest & $\begin{array}{l}\text { http://kso. } \\
\text { metinvestho } \\
\text { lding.com/r } \\
\text { u- } \\
\text { ru/media/n } \\
\text { ews/putesh } \\
\underline{\text { estruj-s- }} \\
\underline{\text { metinvesto }} \\
\text { m-junye- } \\
\underline{\text { izobretateli- }} \\
\underline{\text { edut-v- }} \\
\underline{\text { evropu- }}\end{array}$ & $\begin{array}{l}\text { Competition of scientific and } \\
\text { technical creativity for students of } 8 \\
10 \text { grades }\end{array}$ \\
\hline STEAM-House & $\begin{array}{l}\text { IT-Integrator } \\
\text { Accord Group } \\
\text { STEAM kit }\end{array}$ & $\begin{array}{l}\frac{\text { http://stea }}{\text { m.accord- }} \\
\text { group.com/ }\end{array}$ & $\begin{array}{l}\text { All-Ukrainian competitions in the } \\
\text { design of smart devices }\end{array}$ \\
\hline $\begin{array}{l}\text { Energy efficient } \\
\text { school: a new } \\
\text { generation }\end{array}$ & $\begin{array}{l}\text { DTEK } \\
\text { Academy DTEK }\end{array}$ & $\begin{array}{l}\underline{\text { http: } / / \text { reg.e }} \\
\text { nergyschool } \\
\text { org.ua/mat } \\
\text { erials }\end{array}$ & $\begin{array}{l}\text { Programmes on energy supply, } \\
\text { energy efficiency, conscious } \\
\text { consumption }\end{array}$ \\
\hline
\end{tabular}




\begin{tabular}{|l|l|l|l|}
\hline STEMCamp School & $\begin{array}{l}\text { National Technical } \\
\text { University "Kharkiv } \\
\text { Polytechnic Institute" }\end{array}$ & $\begin{array}{l}\text { https://ww } \\
\text { w.kpi.khark } \\
\text { ov.ua/rus/t } \\
\text { ag/stemcam } \\
\text { p-school/ }\end{array}$ & $\begin{array}{l}\text { Two-week educational programme } \\
\text { for research and implementation of } \\
\text { projects in the fields of energy, } \\
\text { ecology, physics, electronics, } \\
\text { robotics, chemistry, 3-D modelling. }\end{array}$ \\
\hline
\end{tabular}

\section{Conclusion}

The introduction of STEM education in Ukraine is the basis for implementing the strategy of sustainable development of the economy and society. STEM education, having an advanced nature, is designed to solve the following tasks: improving the quality of education itself, updating its content; developing youth innovation; ensuring cooperation between education, science, business and government, bringing education in line with the needs of the economy and society, ensuring gender equality in the choice of education and profession. This educational innovation should form a new cohort of educated young people in Ukraine who are able to work productively to strengthen the competitiveness of their country. The content of STEM education is based on the positive achievements of national and foreign education. The key ideas of STEM as a global educational trend have their own specifics in the national Ukrainian public space. Successful development of STEM education in Ukraine is possible through the creation of a full-fledged programme complex at the national level to provide comprehensive, equitable and quality education, which combines the following elements: experimental research at various levels with a wide range of teachers, students, parents; teachers professional development, the functioning of museums and science centres, the implementation of various educational programmes, festivals and projects to attract young people to STEM, ensuring equal access for girls and boys; during educational process establishing cooperation between educational institutions and external participants, such as academic research institutions, research laboratories, scientific museums, natural centres, enterprises, business structures, public and other organizations.

The STEM concept seeks to offer non-standard solutions to global issues in the field of sustainable development, and STEM education should be considered as a mechanism for accelerating the achievement of all sustainable development goals (SDG) and a component of the strategy to obtain each of them. The structure, principles and key competencies identified as the expected outcome of STEM education prove the justification for considering STEM education as a part of a sustainable development strategy.

\section{References}

Allen, CD. \& Eisenhart, M. (2017). Not Lack of Ability but More Choice: Individual and Gender Differences in Choice of Careers in Science, Technology, Engineering, and Mathematics. Learning Sciences, 26 (3), 407-436. DOI: https://doi.org/10.1080/10508406.2017.1294985

Assembly, G. (2015). Transforming our world: the 2030 Agenda for Sustainable Development Resolution adopted by the General Assembly on 25 September 2015. A/70/L.1. Retrieved from: https://www.unfpa.org/resources/transforming-our-world-2030-agenda-sustainable-development

Asunda, Paul A. (2014) A Conceptual Framework for STEM Integration Into Curriculum Through Career and Technical Education, Journal of STEM Teacher Education: Vol. 49:1,4. DOI: https://doi.org/10.30707/JSTE49.1Asunda 
Bagiati, A. \& Evangelou, D. (2016). Practicing engineering while building with blocks: identifying engineering thinking. European Early Childhood Education Research Journal, 24:1, 6785. DOI: https://doi.org/10.1080/1350293X.2015.1120521

Becker, K., \& Park, K. (2011). Effects of integrative approaches among science, technology, engineering, and mathematics (STEM) subjects on students' learning: A preliminary meta-analysis. Journal of STEM Education: Innovations \& Research, 12 (5-6), 23-37.

Boon Ng, S. (2019). Exploring STEM competences for the 21st century. In-Progress Reflection No. 30, 53 p. Retrieved from: https://unesdoc.unesco.org/ark:/48223/pf0000368485

Debt statistics of Ukraine (2020). [Ministry of Finance of Ukraine]. Retrieved from: https://www.minfin.gov.ua/news/view/osnovnipokaznyky?category=borg\&sucategory=borhova statystyka (Accessed on March 30, 2020) [in Ukrainian].

Dixon, R. A., \& Brown, R. A. (2012). Transfer of Learning: Connecting Concepts during Problem Solving. Journal of Technology Education, 24(1), 2-17.

Murphy, S., MacDonald, A., Danaia, L., \& Wang, A. (2018). An analysis of Australian STEM education $\begin{array}{lllll}\text { strategies. Policy } \quad \text { Futures in } 17 \text { Education, } & 122 \text { - }\end{array}$ 139. DOI: https://doi.org/10.1177/1478210318774190

Nguyen, T. P. L., Nguyen, T. H., \& Tran, T. K. (2020). STEM Education in Secondary Schools: Teachers' Perspective towards Sustainable Development. Sustainability, 12(21), 8865. https://doi.org/doi:10.3390/su12218865

Perez, T., Cromley, J. G., \& Kaplan, A. (2014). The role of identity development, values, and costs in college STEM retention. Journal of Educational Psychology, 106(1), 315-329. DOI: https://doi.org/10.1037/a0034027

Pitt, J. (2009). Blurring the Boundaries - STEM Education and Education for Sustainable Development. Design And Technology Education: An International Journal, 14(1). Retrieved from: https://www.ariadne.ac.uk/DATE/article/view/201

Samsudin, M. A., Jamali, S. M., Zain, A. N. M., \& Ale Ebrahim, N. (2020). The Effect of STEM Project Based Learning on Self-Efficacy among High-School Physics Students. Journal of Turkish Science Education, 17 (1), 94-108 DOI: https://doi.org/10.36681/tused.2020.15

Science on Stage Europe (2020). Sustainability in STEM Education. The European platform for science teachers. Retrieved from: https://www.science-on-stage.eu/page/display/3/104/0/sustainabilityin-stem-education

Smith, C. \& Watson, J.(2016). STEM and Education for Sustainability: Finding common ground for a thrive able future. Proceedings of the 2016 Australian Association for Research in Education (AARE), 27 November - 1 December 2016, Melbourne, Victoria, Australia, 1-11.

Sheffield, R., Koul, R., Blackley, S., \& Maynard, N. (2017). Makerspace in STEM for girls: A physical space to develop twenty-first-century skills. Educational Media International. 54(2), 148-164. DOI: https://doi.org/10.1080/09523987.2017.1362812

Sustainable Development Goals: Ukraine (2017). National report. [Ministry of Economic Development and Trade of Ukraine]. Retrieved from: http://un.org.ua/images/SDGs_NationalReportUA_Web_1.pdf [in Ukrainian].

Teh, Su \& Koh, Hock. (2020). Education for Sustainable Development: The STEM Approach in Universiti Sains Malaysia. DOI: https://doi.org/10.1007/978-3-030-15604-6_35

The concept of the development of natural and mathematical education (STEM education) (2020). [Ordinance of the Cabinet of Ministers of Ukraine, 960-p from 05.09.2020]. Retrieved from: https://zakon.rada.gov.ua/laws/show/960-2020-\%D1\%80\#n8 [in Ukrainian].

Ukrainian Centre for Educational Quality Assessment (2019). Official report on the external independent testing in 2012-2019. Retrieved from: https://testportal.gov.ua/ofzvit/ [in Ukrainian].

UNESCO (2015). Incheon Declaration and Framework for Action for the implementation of Sustainable Development Goal 4: Ensure inclusive and equitable quality education and promote lifelong $\begin{array}{lllll}\text { learning } \quad \text { opportunities } & \text { all. } & \text { ED-2016/WS/28, Retrieved }\end{array}$ from:https://unesdoc.unesco.org/ark:/48223/pf0000245656

Velázquez, Francisco \& Rivas, Fernando. (2020). Education for Sustainable Development in STEM (Technical Drawing): Learning Approach and Method for SDG 11 in Classrooms. Sustainability. 12. 2706. DOI: $10.3390 /$ su12072706 
Wang, MT. \& Degol, J. (2013). Motivational pathways to STEM career choices: Using expectancy-value perspective to understand individual and gender differences in STEM fields. Developmental Review, 33 (4), 304-340. DOI: https://doi.org/10.1016/j.dr.2013.08.001

Wang, M. \& Degol, J.L. (2017) Gender Gap in Science, Technology, Engineering, and Mathematics (STEM): Current Knowledge, Implications for Practice, Policy, and Future Directions. Educ Psychol Rev 29, 119-140. DOI: https://doi.org/10.1007/s10648-015-9355-x

Yanez, G. A., Thumlert, K., de Castell, S., \& Jenson, J. (2019). Pathways to sustainable futures: A "production

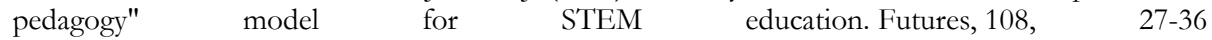
https://doi.org/10.1016/j.futures.2019.02.021

Zgurovsky, M.Z. (Ed.). (2016) Foresight and Construction of the Strategy of Socio-Economic Development of Ukraine on the Mid-Term (until 2020) and Long-Term (2020-2030) Time Horizons. Kyiv: NTUU "KPI"; PH "Polytechnica". [in Ukrainian]. 